\title{
THE VIEWPOINT OF YOUNG MUHAMMADIYAH INTELLECTUALS TOWARDS THE RELIGIOUS MINORITY GROUPS IN INDONESIA
}

\author{
Syamsul Arifin \\ University of Muhammadiyah Malang, Indonesia \\ E-mail: syamsarifin@umm.ac.id \\ Nafik Muthohirin \\ University of Muhammadiyah Malang, Indonesia \\ E-mail: nafikmuthohirin@umm.ac.id
}

\begin{abstract}
Muhammadiyah strives to make a positive contribution to the progress of Indonesia. In the first century of the advent, this organization focused on advancing education, health, and compensation to the $d u^{\prime} a f a a^{\prime}$. Meanwhile, it issued an important point, which emphasized the minority groups through the $47^{\text {th }}$ Congress in Makassar held in 2015. Hence, this article examines several issues concerning the views that underlie young Muhammadiyah intellectuals in voicing partiality towards the religious minority. It also analyzes the role or form of alignments and the implications of these views on thought upheavals within Muhammadiyah internally and nationally. The study discovered that the young intellectuals play a pivotal role in fighting for the basic rights of the religious minority, which continues to face the complicated problem of citizenship. Subsequently, this data has been focused on advocacy and intellectual works, including a literature review of attitude statements, published books, journals, research reports, and opinions in the national mainstream and alternative media.
\end{abstract}

Keywords: Young Intellectuals; Muhammadiyah; Religious Minority; Human Rights.

\section{Introduction}

The study of Muhammadiyah and its relationships with the religious minority groups in Indonesia are not new in Indonesia. Various studies on especially some or few encounters between the 
two have been made before among others by Alwi Shihab, ${ }^{1}$ Herman L. Beck, ${ }^{2}$ Melissa Crouch, ${ }^{3}$ Jeremy Menchik, ${ }^{4}$ Gustav Brown, ${ }^{5}$ Abdul Mu'ti dan Fajar Riza Ul-Haq, ${ }^{6}$ Ismatu Ropi, and Ahmad Najib Burhani. ${ }^{8}$ Each expert has his perspective, for instance, Beck, Ropi, and Burhani emphasized on the encounter between Muhammadiyah and Ahmadiyya, while Mu'ti, Fajar, and Shihab pointed out the involvement of Muhammadiyah and the Christians in the field of education. The studies explain that Muhammadiyah possesses a long history with the religious minority groups either the relationship knitted with harmony or that interspersed with tension.

From the preliminary researches above, no research that has been focused on the young Muhammadiyah intellectuals as the object of study in viewing the relation between Muhammadiyah and the religious minority groups in Indonesia has been conducted. Their involvement in this discourse is very vital for two fundamental reasons: firstly, the existence of young Muhammadiyah intellectuals as the center for progressivity in the body of the contemporary Muhammadiyah, and secondly, understanding their involvement, views, and alignment in struggling the religious minority groups.

For the first reason, a number of thinkers such as Budhy Munawar-Rachman, Zuly Qadir, Ahmad Syafii Maarif, and Carool Kersten confirm the statement. For instance, Budhy Munawar called

\footnotetext{
${ }^{1}$ Alwi Shihab, "The Muhammadiyah Movement and Its Controversy with Christian Mission" (Dissertation--Temple University, 1995).

2 Herman L. Beck, "The Rupture between the Muhammadiyah and the Ahmadiyyah", Bijdragen tot de Taal, Land-en Volkenkunde (BKI), 161-2/3 (2005), 210246.

3 Melissa Crouch, Indonesia, Militant Islam, and Abmadiyya: Origins and Implication (Melbourne: ARC Federation Fellowship, Centre for Islamic Law and Society, Melbourne Law School, University of Melbourne, 2009), 4-6.

4 Jeremy Menchik, Islam and Democracy: Tolerance Without Liberalism (Cambridge: Cambridge University Press, 2016).

5 Gustav Brown, "Civic Islam: Muhammadiyah, NU and the Organisational Logic of Consensus-making in Indonesia", Asian Studies Review, Vol. 43, No. 3 (2019), 398402.

${ }^{6}$ Abdul Mu'ti and Fajar Riza Ul-Haq, Kristen-Mubammadiyah: Konvergensi Muslim dan Kristen dalam Pendidikan (Jakarta: Al-Wasath Publishing House, 2009).

7 Ismatu Ropi, "Islamism, Government Regulation, and the Ahmadiyya Controversy in Indonesia”, Al-Jamiah, Vol. 48, No. 2 (2010), 76-98.

8 Ahmad Najib Burhani, "The Ahmadiyya and the Study of Comparative Religion in Indonesia: Controversies and Influences", Islam and Christian-Muslim Relations, Vol. 25 (2013), 1-18.
} 
the young Muhammadiyah intellectuals as an umbrella for intellectual superiority in the body of Muhammadiyah.' Through the Maarif Institut, the young Muhammadiyah intellectuals voice and convey to the public on the style of Indonesian Islam which is open, anti violent, and is always standing on the harmony of the state-nation principles. It is also revealed by Karstein's view, that the young Muhammadiyah intellectuals are as a group that enlivens the study of the present Islamic thoughts, especially on the topics of Islam-West dialogues to find a key to solve any religion-based conflicts. ${ }^{10}$ Whereas for the second ground, it is this article that will describe many things dealing with their viewpoints, involvements, and alignments in fighting the citizenship rights of the religious minority groups in Indonesia.

The encounter of Muhammadiyah with the minority groups has passed a long history. Muhammadiyah once was near with Ahmadiyya from around 1924 to 1925 . The prominent figures such as Djojosugito (Secretary I Muhammadiyah), Muhammad Husni (Secretary II Muhammadiyah), and a number of teachers of HIS Muhammadiyah and students of Kweekschool Muhammadiyah among others Soedewo, M. Kusban, Sunarto, Sunarto, Usman, Muhammad Irsyad, and Mufti Syarief are a number of names that are noted to once have a close relationship with Ahmadiyya. Even, Ki Bagus Hadikusumo together with some other leaders of Muhammadiyah and Sarekat Islam (Islamic Union) once came to the house of Mirza Wali Ahmad Baiq, a dai (revival mullah) of Ahmadiyya in Lahore, India to learn English and to discuss Islamic da'wah. At first, this relation was very close "since it was considered to have a vision of Islamic purification and thought modernization," but at last, there were many cadres of Muhammadiyah becoming the followers of Ahmadiyya, and this caused some breaks so that the relation between the two lasted shortly. ${ }^{11}$

An expert of Muhammadiyah, Ahmad Muarif stated the closeness between Muhammadiyah and the Chinese minority group could be seen in the implementation of the $15^{\text {th }}$ Yearly Congress in

9 See in Budhy Munawar-Rachman, Reorientasi Pembaruan Islam: Sekulerisme, Liberalisme dan Pluralisme Paradigma Baru Islam Indonesia (Jakarta: Pusat Studi Agama dan Multikulturalisme-The Asia Foundation, 2010), 111.

10 Carool Kersten, Berebut Wacana: Pergulatan Wacana Umat Islam Indonesia Era Reformasi, trans. M. Irsyad Rafsadie (Bandung: Mizan, 2018), 63.

11 Beck, "The Rupture between the Muhammadiyah", 210-246. 
1926. He explained that the Chinese community had a great contribution to the success of the Congress. The Chinese community cheered up the Congres by contributing some donations and great publication in the Sin Po magazine, a prominent daily newspaper belonging to the Chinese ethnic group published from 1910-1965. K.H. Ibrahim as the Hoofd Bestuur Muhammadiyah intentionally invited the Chinese ethnic group to come to Congress. When they were listening to the speech given by Nyi Walidah, KH. Ahmad Dahlan's wife, they were impressed with her ability to give a speech, so that the wives from the Chinese community tried to imitate the advancement of the Aisiyah. ${ }^{12}$

In the sector of education, Muhammadiyah has possessed at least six Muhammadiyah Higher Education (Perguruan Tinggi Mubammadiyab/PTM) in the areas of which their majority of the population is not Moslem, namely The University of Muhammadiyah Sorong, University of Muhammadiyah Kupang, Institute of Teacher Training and Education Muhammadiyah Maumere, STIKOM Jahapura, College of Education Muhammadiyah Kupang, Institute of Teacher Training and Education Muhammadiyah Manokwari, and College of Education Muhammadiyah Sorong. The Chairman of Research and Development Higher Education Council of the Central Board of Muhammadiyah Lincolin Arsyad explained that on the campuses, the number of non-Moslem students is around $60 \%$ $80 \% .{ }^{13}$ Even it is a guide to learning al-Islam and Kemubammadiyahan (AIK) under a multicultural perspective has been being designed.

\section{The Roles of Young Muhammadiyah Intellectuals}

Muhammadiyah has played its vital roles in voicing its alignment to the religious minority groups in Indonesia. The roles of the alignment are realized in some forms, such as actions in social advocacy and intellectual works in the form of statements of attitudes, research reports, books, journal writings, article publication in mass media either done individually or in groups, or institutionally. Recently, in some of its articles, Suara Mubammadiyah, ${ }^{14}$ as an official

12 Interview with Ahmad Muarif di Kantor PP Muhammadiyah Yogyakarta on 1 July 2019.

13 Speech delivered by Lincolin Arsyad in "Workshop Panduan AIK untuk NonMuslim" di UMM Inn Hotel Malang on 4 November 2017.

14 Suara Muhammadiyah is an official magazine of the Central Board of Muhammadiyah. It was pioneered by K.H. Ahmad Dahlan and Haji Fachrodin, 
publication Central Board of Muhammadiyah, has published some articles discussing "mainstreaming the existence of the religious minority groups. ${ }^{15}$ But, studies of religious minority groups are still limited in number. ${ }^{16}$

A number of Muhammadiyah elites such as Haedar Nashir (Chair of Central Board of Muhammadiyah), Abdul Mu'ti (Secretary of Central Board of Muhammadiyah), Ahmad Syafii Ma'arif (Chair of Central Board of Muhammadiyah in the 1998-2005 period), Abdul Malik Fadjar (Chair of Central Board of Muhammadiyah in the 20052010 period) and now members of the Presidential Advisory Board and Siti Ruhaini Dzuhayatin (Higher Education Council of the Central Board of Muhammadiyah in 2015-2018 period, President's Special Staff for the International Religious Field are properly said as the figures of the Muhammadiyah elites possessing some concern with voicing the rights of the religious minority groups in Indonesia.

Then, institutionally, what is clearly shown by Muhammadiyah in confirming its attention to the religious minority groups in Indonesia may be seen through its $47^{\text {th }}$ Congress in Makassar (2015). It happened to the Commission IV, a recommendation group studying strategies issues. One of the emerging topics is the urgency for Muhammadiyah to give respect, appreciation, and protection to religious minority groups. In its session, this group discussed the importance of Muhammadiyah to serve as a peaceful mediator between Sunnī and Shī'ah groups in Sampang. This Commission was lead by Abdul Mu'ti and Abdul Malik Fadjar. Abdul Mu'ti told in the

\footnotetext{
Magazine Suara Muhammadiyah (Soeara Moehammadijah) was first published in bulan Dzulhijjah year 1333 H (1915 M). Suara Mubammadiyah that has reached its age of one century has consistently been published once in two weeks with the motto: "Strengthening and Enlightening". Due to its consistency in publication up to now, this magazine has been awarded a MURI record as the oldest and the most existing magazine in Indonesia in 2016.

15 Some articles on minority groups are presented in Suara Muhammadiyah, such as those written by Ahmad Najib Burhani, "Kelompok Minoritas sebagai Kategori Mustad'afin", Suara Muhammadiyah (15 February 2019); Nafik Muthohirin, "AIK Non-Muslim: Menjawab Tantangan Pendidikan Islam", Suara Mubammadiyah 24/102. Edisi 16-31 December 2017; "Perkuat Kebersamaan: Muhammadiyah Gelar Silaturrahim Lintas Agama", Suara Muhammadiyah (6 August 2016); "Tokoh Agama belum Berperan Maksimal Wujudkan Toleransi”, Suara Mubammadiyah (10 August 2016).

${ }^{16}$ Interview with Ahmad Muarif di the Office of Central Board of Muhammadiyah, Yogyakarta on 1 July 2019.
} 
book authored by Ahmad Najib Burhani (2019) that the situation of the session held by the commission was like the oration of independence. Aven, there were local administrators proposing that Muhammadiyah took a substantial part in Ahmadiyya whether it is included in the Muslim or non-Muslim category. ${ }^{17}$

Honestly, some prominent people behind the concept of formulating strategic issues, especially those dealing with religious minority groups and inter-school in the Recommendation Commission are Ahmad Najib Burhani, Muhammad Riefqi Muna and Alpha Amirrachman. ${ }^{18}$ The three persons are young Muhammadiyah intellectuals prolific in his own field. Various analyses of their ideas on the dynamics of nationality may be easily found in various national media, and they also often color a discourse of religious thoughts, education, and politics in this country. Riefqi Muna is a researcher of the Indonesian Institute of Sciences (LIPI) in the field of International Politic Development, while Alpha Amirrachman held a position as the Director of SEAMEO Regional Open Learning Centre (SEAMOLEC), Ministry of Education and Culture. Then, Ahmad Najib Burhani is a researcher of LIPI with expertise in the field of religion, philosophy, and system, religion and religious tradition.

Since Najib was a student in UIN Syarif Hidayatullah Jakarta, he has been interested in the scientific field of inter-faith, schools in Islam, philosophy, ancestral religious, and religious minority groups. His alignment to Ahmadiyya started when its congregation was aggressed in Kampus Mubarak, Parung (2005). It is this incident that makes Najib make a turning point from a student who was busy to attend one discussion to the next, to theorize, and to "solve" problems through discussions and writings, then to lead him to play a greater role by giving guidance to the heart of the problems.

In the field of research, Najib has studied Ahmadiyya for years. In 2012, he visited room in the hostel in Transito, Mataram, West Nusa Tenggara, in which congregation Ahmadiyya Lombok stayed and they have experienced expulsions many times since 2002. Najib can feel the sufferings, difficulties, and discomfort that happened to 140 members of Ahmadi staying in the hostel after they had been

17 Read in Ahmad Najib Burhani, Menemani Minoritas: Paradigma Islam tentang Keberpihakan dan Pembelaan kepada yang Lemah (Jakarta: Gramedia, 2019), 12-13.

18 Ibid., 13. 
expelled, alienated, attacked and their houses had also been destroyed and looted before. ${ }^{19}$ In 2016, he joined into Jalsa Salana Qadian in India, so that he had an opportunity to visit Dar al-Masih (Mirza Ghulam Ahmad's house), saw Masjid Al-Aqsa (a mosque build by Mirza Ghulam) and Minaratul Masih, Bahishti Maqbarah (tombs of Mirza Ghulam and followers of Ahmadi), Hoshiarpur (a place where Mirza Ghulam mediated, and accepted revelation), and Ludhiana (a place for the first oath). ${ }^{20}$

Clearly, Najib's expertise in the field of alignment to Ahmadiyya group cannot be put into doubt. His intellectual standing is strengthened when he became an expert judicial review Law No. 1/PNPS/1976 in the Constitution Court sued by the Jemaah Ahmadiyah Indonesia (JAI) (Indonesian Ahmadiyya Congregation) in November 2017. On the basis of his education, experiences, encounters and his research activities, Najib before the Constitution Court Committee and pers bravely stated that a claim of misdirection to Ahmadiyya is improper. Prejudice and unilateral accusation made by the non-Ahmadi community has made people misunderstand Ahmadiyya's teaching. Tarkirah is not a holy book of Ahmadiyya. It is al-Qur'ān which is their holy book. Then, any praise and approbation given to Ghulam Ahmad are not higher than the Proper Muhammad Saw. ${ }^{21}$ The book written by Ahmad Najib Burhani with the title of Menemani Minoritas: Paradigma Islam tentang Keberpihakan dan Pembelaan kepada yang Lemah (2019), is a form of commitment and confirmation of the role of the young Muhammadiyah intellectuals in their alignment to the religious minority groups.

Young Muhammadiyah intellectuals who are always moving and voicing their alignment to religious minority groups are Sudarto, Ismail Hasani, Yulianti Muthmainnah, Ahmad Fuad Fanani, Rita Pranawati, and Subhan Setowara. Sudarto once held a position of Chair of Muhammadiyah Student Association (now Muhammadiyah Student Association), Kerinci area (1992-1997). He once worked in Aliansi Nasional Bbinneka Tunggal Ika (ANBTI) and Setara Institute to give socio-economic services to religious minority groups. His book with the title of Religionisasi Indonesia: Sejarah Perjumpaan Agama Lokal dan Agama Pendatang (2016), is authentic evidence of his ideas and

\footnotetext{
${ }^{19}$ Ibid., 151-154.

20 Ibid., 106-119.

${ }^{21}$ Kompas, 7 November, 2017.
} 
actions to his alignment towards religious minority groups in Indonesia. It is through this book that Sudarto shows how the behaviors of the "immigrant religion", higher educations, and academicians, ${ }^{22}$ and the government under the name of the state wipe out the roles played by the local wisdom previously possessed by the local religions. Together with Ismail Hasani in Setara Institute, Sudarto makes yearly research to understand any behavior of intolerance and discrimination of the rights of citizenship experienced by the groups of faith believers

Ahmad Fuad Fanani also strictly responds to the process of democratization that is seriously challenged by strong sectarianism politics. Commitment to keep diversity and pluralism is threatened by a variety of violent actions that are often experienced by religious minority groups such as Ahmadiyya, Shia, Lia Eden, and adherents of local religions. According to him, religious groups outside the belief mainstream believed by Indonesian people are always subordinated and marginalized since they are considered to have been out of the official religions recognized by the state, therefore, it is appropriate that they are expelled. They are also often labeled deviant so it is lawful if they are killed because they are perverted from Islam, and defile other religions on the basis of justification of certain fatwas. ${ }^{23}$

Meanwhile, Yulianti Muthmainnah defends religious minority groups through policy advocacy to the government. Yulianti once worked for the National Women's Commission from February 2007 to December 2013. She occupied two important positions in the Commission namely the Division of Law Reformation and Assistant to the Head for International Relation and Institution for six years. In the Division, she contributed to advocate some policies directly related to the rights of citizenship of religious minority groups. Firstly, together with faith believers studied and sued a lawsuit of Article 61 verses 1 and 2 of the Law on Population Administration to the Constitutional Court about the "Column of Faith Believers in Identity Card" from 2010 to 2011. The Constitutional Court at last granted the lawsuit of the verses in 2017. Secondly, in cooperation with the

22 Higher education and academicians play vital roles in discriminating against the adherents of local religions by categorizing them as "animism" and "dynamism". For them, such a categorization model is a form of discrimination. See in Sudarto, Religiosasi Indonesia, iv-xi

23 Ahmad Fuad Fanani, "Kebinekaan di Persimpangan Jalan". Koran SINDO, “Opini”, Thursday, 2 July 2015 
indigenous people struggled to get rights for ulayat land in the Constitutional Court in 2012. Although the Court at that time had granted this lawsuit through its Decision No. 35/PUU-X/2012, the rights of the indigenous women, as the focus of the struggle made by Yulianti, were still not given any right from the distribution of the ulayat land. According to her, up to now, the government has not fully given protected forest or ulayat land to indigenous people. Thirdly, she oversaw and asked for the Constitutional Court to revise the Law No. 1 on PNPS year 1965 and to take firm actions to any intolerance and/persecution to religious minority groups. According to her, the Law is a form of discrimination under the legal umbrella to minority groups. $^{24}$

Her activities in giving advocacy to policies of the rights of citizenship to religious minority groups were often given bad treatment by the parties opposed to what she has been struggling with. She admitted that she was once cried as an unbeliever in three different court sessions, especially when she watched over the revocation of the Law No. PNPS year 1965 which she considered not to be friendly to the religious minority women. ${ }^{25}$

More broadly, some other young Muhammadiyah intellectuals are also involved in expressing the religion diversity namely Pradana Boy ZTF, Piet Hizbullah Khaidir, Zuly Qadir, Abdul Rohim Ghazali, Choirul Mahfud, Muhammad Abdullah Darraz, Fajar Riza Ul-Haq, Raja Juli Antoni, Hilman Latief, Wahyudi Akmaliah, David Krisna Alka, Zakiyuddin Baidhawy, dan Moh, Shofan. The young Muhammadiyah cadres have their own expertise, work on their own issues, research their own field, give socio-economic services, make audiences with government institutions, and disseminate their thoughts and encounters with a variety of the religious minority groups that always experience some discriminations through scientific publications: books, research reports, journals, popular articles, opinions, statements of attitudes, and various forum of seminars and scientific discussions.

\footnotetext{
24 Yulianti Muthmainnah, "In the Name of Majority, Forgotten of Minority", presented in the Winter School on Pluralism and Development Program, by International Institute for Studies in Race, Reconciliation and Social Justice at the University of the Free State in Bloemfontein South Africa in cooperation with the University for Humanistic Studies in the Netherlands, Bloemfontein - South Africa from 16 July 10 Aug 2012.

25 Interview with Yulianti Muthmainnah on 7 August 2019.
} 
Various strategic issues they consider include among other the right of citizenship among the faithful believers' groups, treatments of discrimination and persecution to Ahmadiyya congregation, threats of violence and expiration to Shia adherents, the prohibition to nonMuslim leadership, women's right to ulayat land, environmental destruction of the ulayat land, religious identity politics, proscription of establishing houses of worship, interfaith dialogues, multiculturalism; religious life harmony, freedom of religion and belief; human rights and tolerance.

Wahyudi Akmaliah, for example, through his statuses in Facebook and various articles in a lot of online pages like GeoTimes, Islami.co. and Mojok.co, clearly shows his alignment to defend a nonMuslim leadership when Basuki Cahaya Purnama (Ahok) run for the candidate of the governor of DKI Jakarta in 2017. When he was stricken by an issue of "blasphemy", this Indonesian Institute of Sciences (LIPI) researcher clearly stated that the sentence of two years in prison to Ahok, who is non-Muslim and from the Chinese ethnic group, was caused by the mass pressure under the name of religious rules. Wahyudi said that the court had submitted to the mass pressure in a religious cloth. ${ }^{26}$ It is in the same vein as what was conducted by Moh. Shofan, Abdul Rohim Ghazali, and Muhammad Abdullah Darraz in responding to the injustice felt by Ahok.

In general, attention is given by the young Muhammadiyah intellectuals to the religious minority problems positively show their attitudes towards plurality. In their views, plurality in religion and belief is an irrefutable necessity. What they attend is the incidences of conflicts and violence accompanying the plurality of religion. For them, such violent practices in the area of religion are a paradox that should not occur. They depart from the normative view that all religions sent down to earth equally bring the main mission, among others: peace. Their viewpoint is strengthened using a perennial philosophy perspective that every religion has its own universal reach that may pass through esoteric limits of religion.

The perennial philosophy intends to reveal an important fact existing in all religions, namely a unity of message that may essentially strengthen an inter-faith relation, although there are some differences at the esoteric level. On the basis of a viewpoint that at a normative

26 Wahyudi Akmaliah, "Tekanan Massa dan Vonis 2 Tahun Ahok", Geotimes, Tuesday, 9 May 2017. 
level religion is full of perennial messages, any religious conflict and violence in the young Muhammadiyah intellectuals' views should be traced in an area they call religious historicity. As an implication of the religious fact which is a part of human historicity, there is always a tendency that a religion deviates from the normative frame. A part of the human historicity, for example, is the human effort to look for answers to his self-existence in this universe. A human being may quest an answer to this question in other institutions outside religion, for example, philosophy, ideology, or sciences. However, according to them, what is recognized to be able to provide the answer is religion, since the matter of human existence is related to how to orient one's life in a reality possessing the meaning of eternity, authenticity, and absoluteness. This problem cannot be answered by merely depending on human rational reasoning such as that has been tried by philosophy, ideology, and sciences. It is at this point that religion may play a role that cannot be made by other institutions. But, it even starts from here that religion can go out of its normative frame.

Answers to any problems of human existence will reinforce the position as the source of the finding of self-identity and of group identity. In this position, religion is made as to the shaper of the group and self-identity that certainly potential to create what is in the anthropology called a bounded system. Then, a psycho-sociologic attitude in the group and in group feelings emerges. This does not end. To fortify the group identity, a religious community reinforces it by developing great narrations with the source from an absolute authority and building up certain religious expressions at a massive scale, and certainly, also a public expose of one of the characteristics which are intended to show in order to confirm a group identity before other groups. All of these in the young Muhammadiyah intellectual outlook just improve the robustness of self- and groupidentity and confirm differences among many people and groups.

The interest in the study of and the focus of attention to this alignment issue were enhanced owing to the activism of the young Muhammadiyah intellectuals since they were student activists in Ikatan Mahasiswa Mubammadiyah (IMM) (Muhammadiyah University Student Bond), Ikatan Pelajar Mubammadiyah (IPM) (Muhammadiyah University Student Association) and Himpunan Mahasiswa Islam (HMI) (Islamic Student Association). When they were active in the student movement, they were deeply dissolved in the readings of books on 
social theories, new social movement, on the study of Western and Eastern philosophies, and schools in Islam. Even, some of them also studied the Holy Qur'an using various methods and approaches, so that they have grown their critical, inclusive and transformative awareness in their behavior of diversity. They believe that the Islamic doctrine is always harmonious with the spirit of the era. The problem is that in a real-life, they have also found that a variety of socioreligious problems encountered by the ummah are not fully different from those during the early Islamic period or the social reality existing in their reading materials. Discrimination, subordination, primordialism-based violence, and judgment to different groups always happen from time to time but at different times, places and forms of the problems.

The forging continued when the young joined in the Jaringan Intelektual Muda Muhammadiyah (JIMM). In 2005, also through JIMM, a number of young people such as Budi Ashari Afwan, Andar Nubowo, Isngadi, Zuly Qadir, Nurlia Dian Paramita, Ahmad Najib Wiyadi, Kuni Khairunnisa, and Thufail AM made communications with the Christian community in GKI Gejayan Yogyakarta that faced problems with the surrounding community who are incidentally Muslim dealing with the building of house of worship. They tried to be the mediator between the two parties by often conducting studies and sharing in their places alternately. Yet, being initiated by the young Muhammadiyah intellectuals, they held a youth inter-faith camp in Kaliurang together, including the participants from the church youth from GKI Gejayan. On other occasions, they also established a hermitage Sumbu Panguripan in Panggang sub-district, Gunungkidul regency, Yogyakarta. Sumbu Panguripan becomes the place for the local people with different faith backgrounds (Islam, Christian, Buddhism) to meet and discuss one another, to join in the entrepreneurship skills, and to raising living stocks, and also as the learning place for the children around the area who mostly drop out of school.

Among the young, they are still active to work on the issue of the religious minority, but they also pursue their own professional jobs. Up to now, Budi Ashari has become research in the Center for Religious and Cross-cultural Studies (CRCS) Universitas Gadjah Mada Yogyakarta. From 2007 to 2013, he was involved in research programs on a number of problems of the house of worship in 
Indonesia that once happened in Bekasi, Bogor, Bali, and Manado. Each problem in establishing a house of worship has various conflict roots. Blame one of the parties cannot be made. But, it is a dialogue that becomes the clue to ease the tension between the two parties. ${ }^{27}$ Therefore, a peacemaking strategy is an effort made to avoid the community from a quarrel, since usually those who are involved in a dispute often show their group fanatism and primordialism.

The rationale serving as the basis for the young Muhammadiyah intellectuals to be active in working on the religious minority issues starts with some of the following factors. Firstly, Muhammadiyah as a religious organization always prioritizes socio-empowerment movements. This is reflected in KH. Ahmad Dahlan who was highly concerned with the mustad'afin group. Secondly, a progressive interpretation of the verses in the Holy Qur'an containing struggles to the mustad'afin group, as stated above, refers to the Moeslim Abdurrahman's (Kang Moeslim) thought, which is transformatively meant as the "the new mustad'afin" group, namely the people who are socially and culturally oppressed. The existence of the people in the new mustad'afin cycle, Kang Moeslim says, needs a "newly social theology" to free them from such "social wickedness". ${ }^{28}$ Thirdly, it seems that the advanced type of interpretation strongly influenced the thoughts of the young Muhammadiyah intellectuals joined in JIMM. ${ }^{29}$

Moreover, another significant factor promoting the progressive young peoples who were greatly interested in Kang Moeslim's thought is his idea that often places the religious texts near problems of social realities. They respect and appreciate Kang Moeslim as their teacher and also a friend in sharing knowledge. Pradana Boy writes that Moeslim is a "strong intellectual mentor" for young Muhammad-

\footnotetext{
27 Interview with Budi Ashari Afwan on 16 August 2019.

28 Moeslim Abdurrahman, Suara Tuhan, Suara Pemerdekaan (Yogyakarta: Kanisius, 2009), 185-190.

${ }^{29}$ JIMM is a young Muhammdiyah generation who feels that the intellectual and thought movement in Muhammadiyah is stagnant. JIM was born to respond to the dynamism of Islamic thoughts in Muhammadiyah although the response back was given by Muhammadiyah's party varies. As a community working in the field of thought, JIMM does not possess a bonding membership system but possesses a number of presidium serving as the coordinator of a variety of activities. JIMM was born in October 2003 in Bogor through a workshop organized by Ma'arif Institute for Culture and Humanity, Jakarta.
} 
iyah intellectuals. ${ }^{30}$ For the writers, the use of the word "strong intellectual mentor" actually is intended to delineate their admiration to Kang Moeslim as an "excellent pedagogue" who taught sciences and at the same time encouraging to realize knowledge of transformative social works. Amid the intellectual lethargy occurring in the body of Muhammadiyah at that time, the presence of Kang Moeslim as an advisor, mentor and also mentor for young Muhammadiyah people became a momentum of the intellectual revival. It is through Kang Moeslim that the young Muhammadiyah people were taught not to be anti-local cultures. Muhammadiyah becomes an advanced movement by giving attention to the labor, fishermen and farmer groups. ${ }^{31}$ His book with the title of Kang Towil dan Siti Marjinal (2002) is the embodiment of his alignment to the proletarian group. According to Budi Ashari, it is the mindset of defending the proletarian group that really the essence of what has been taught by Kang Moeslim so far. ${ }^{32}$

Young Muhammadiyah people who were guided by Kang Moeslim around 2002s to 200s are now going out from the "hard orientation", they have graduated from a variety of prestigious universities abroad and will always give benefits especially for the internal organization, and the state in general. It seems that the progressivity of their thoughts and movements clearly fills in strategic position in The Central Leader of Muhamamdiyah like Hilman Latief (Director of Amil Zakat, Infaq dan Shadaqah Muhammadiyah Institution/Lazismu); Andar Nubowo (Fund Rising dan Lazismu Cooperation; Ahmad Najib Burhani (Vice-Chair of References and Information); Fajar Riza Ul Haq (Secretary of Law and Public Policy Institute; Zakiyuddin Baidhawy and Izza Rahman (Lazismu Sharia Board); in the government there are some names namely Pradana Boy ZTF (Assistant for the President's Special Staff of the President of the Republic of Indonesia in the International Religion Field); Zuly Qodir (Expert in Pancasila Ideology Guidance Agency/BPIP); Rita Pranawati (Indonesian Children Protection Commissioner/KPAI); Alpha Amirrachman (Director SEAMEO Regional Open Learning Centre of the Ministry of Education and Culture/SEAMOLEC

30 Pradana Boy ZTF, "Kang Moeslim, Selamat Jalan (Mengenang Moeslim Abdurrahman 6 July 2012)". Geotimes, rubrik "Kolom”, Thursday, 6 July 2017.

31 Ahmad Najib Burhani, "Kang Moeslim dan Muhammadiyah", Kompas, 9 July 2017.

32 Interview with Budi Ashari on 16 August 2019. 
Kemendikbud); and in political parties, there is Raja Juli Antoni (Secretary-General of Partai Solidaritas Indonesia/PSI (Indonesian Solidarity Party).

Besides Kang Moeslim, another figure inspiring the young Muhammadiyah intellectuals to consistently show alignment to the minority groups is Ahmad Syafii Ma'arif (Buya Syafii). His attitudes and writings in Mass media that show that he always "stands together" with the minority group explains his consistency to play a great role at the nationality level. Buya Syafii is not a new figure who speaks and defends the freedom of religion and belief, he is also the one who greatly respects the diversity and urgency in struggling the minority group. He is an old person who always has a spare time to associate and mingle with young Muhammadiyah people. From the close association, at last, he possesses an optimism of the great potency of young Muhammadiyah people to create an order of democracy to protect all parties in the future.

In a long enough comment, Buya advises that the young Muhammadiyah intellectuals should be trapped into a radicalism movement, give a priority of the group interest, and show an inclusive view in looking at diversity. He says:

"To the young intellectuals of Muhammadiyah and NU, I expect that they think of an Indonesian Islamic building in the orientation of their innovative and creative thought. Up to a certain limit, I have often dialogues and associate with the mainstream of the young. My conclusion is that their attitudes have been already open, different from the old generation who are often short-sighted". ${ }^{33}$

In another paragraph, he strengthens his argument that the young Muhammadiyah people should be brave to control the leadership of the nation, guard the cultural basis of the grassroots, and keep the harmony of diversity by saying the following:

"In my mind, a wise attitude is that they should stay in the mainstream by keeping a high power criticism, being sincere while creating a realm conducive to the emergence of a new and fresher generation of leadership with moral-intellectual integrity recognized by all parties, whatever parameter used. The young generation of Muhammadiyah and NU should always make intensive dialogues in the effort to formulate and place a good

33 Read fully in Ahmad Syafii Maarif, Islam dalam Bingkai Keindonesiaan dan Kemanusiaan: Sebuah Refleksi Sejarah (Jakarta: Mizan, 2009), 316. 
format of the relation between Islam and Indonesianness. A movement towards the end has begun, but it still needs a more sharp vision so that the emerging image of Islam is Islam that protects all parties. The War drum beaten by a few people should be faced with a drum of peace, justice, politeness, inclusivism, and pluralism using a full prestige manner since we are sure to the true principle we believe in". ${ }^{34}$

Arguments provided by Buya Syafii have a deep message and are full of optimism, expecting that this nation, especially the young, keeps its diversity. He understands that differences possessed by Indonesia may become a serious threat if there are some parties or groups whose interests are not accommodated. Conflicts occurring due to religious fanatism and ethnicity in Maluku and Central Kalimantan are a dark history of this country that has reflected a variety of religious diversity covering religions, ethnic groups, tribes, languages, traditions, and cultures. In the context of religious diversity, Al-Makin describes that this archipelago was a fertile place for the emergence of a new religious movement from the $10^{\text {th }}$ century to the $20^{\text {th }}$ century. ${ }^{35}$

Consequently, when the Buya Safii took sides of Ahok in the case of "blasphemy" in 2017, which was cursed by many parties, those who clarified and also defended him certainly came from the young people from Muhammadiyah, Buya Safii's student. In this case, the young Muhammadiyah intellectuals not only defend Buya Syafii, but also the rights of the minority group. The noise considered to be "blasphemy" is a failure of Islamic parties that are unable to bear leaders.

In this matter, either Kang Moeslim or Buya Safii have provided a wide enough room for the young Muhammadiyah people to express their thoughts, especially Islamic and social ones. He is the teacher of this nation that should be modeled in raising the dignity of the mustad'afin, either those who are structurally or culturally oppressed. Kang Moeslim has inherited various concepts of ideology and social change movement such as among others: "Islam

\footnotetext{
34 Ibid., 317.

35 This fact is influenced by "the change in the faith among the Javanese people that flow in line with the dynamic of the power of various kingdom with different traditions of Hinduism-Buddhism, Mataram, Wisnu Kediri, Shiva Majapahit, Islamic syncretism of Demak, Surakarta and Yogyakarta." See further in Al Makin, Nabinabi Nusantara: Kisah Lia Eden dan Lainnya (Yogyakarta: SUKA-Press, 2017), 8-9.
} 
Transformatif (Transformative Islam)," "Teology al-Maun (al-Maun Theology)," "Kemungkaran Sosial (Social Evil)," and "Kang Towil dan Siti Marjinal". The terms are not merely intended to sweeten statements various types of the work of his thoughts. The terms reach above their meanings, they reincarnate to become a foundation of thought which is at the same time a movement realized various practices of freedom which are always voiced by young Muhammadiyah intellects who once studied to him, either directly or indirectly, namely by making meetings through smart thoughts spread in his many books and articles. Meanwhile, Buya Syafii, borrowing from Haedar Nashir's term, is an old person and also a national figure who always becomes an "Eagle without nest" who is also to be able to fly high in the sky, he does not build a dynasty for himself and his family at all, but he establishes a greatness for Muhammadiyah and the state.

\section{Urgency of Objetivation}

Kuntowijoyo in his preface in the book authored by Alwi Shihab (2016) explains that Muhammadiyah will face a serious challenge in the future, remembering this the characteristic of this nation is very complex, either in terms of religions, cultures, and knowledge. ${ }^{36}$ This challenge comprises an internal and external one. In the internal challenge, Muhammadiyah should reform its social movement and thought due to the emergence of a new era in diverse fields of life, starting from alternative education, social relations, needs of urban community, environment, and health services. Meanwhile, from the external challenge, diversity as a necessity cannot be avoided by Muhammadiyah all the time. On one occasion, Muhammadiyah may refuse it (from the response of refusal to Tafsir Tematik Al-Qur'an tentang Hubungan Sosial Antar Umat Beragama (Pustaka SM dan MTTPI: 2000)), but since diversity is given, Muhammadiyah can't avoid being involved in handling problems of diversity in this new era. The matter of diversity, which among others contains problems of citizenship of the religious minority groups. It is an objective matter, therefore, Kuntowijoyo reminds that Muhammadiyah should try to objectify Islamic teachings which are rahmah li al-älamin. The form of Muhammadiyah objectivation is to

\footnotetext{
36 This book was firstly published by Mizan with the same title in 1998 and was republished by Suara Mubammadiyah in 2016.
} 
provide all people with the feeling of security, justice, and peace, regardless of different races, skin colors, religions, and the like. ${ }^{37}$

Any response of refusing various alignment made by the young Muhammadiyah intellectual with the religious minority groups in the body of Muhammadiyah occurring in the previous period can be used as a lesson. In line with the challenges of the times which cannot be avoided and the fact of diversity as a necessity, in fact, this organization cannot stay away from the crisis of diversity matter that occurs at the moment. Muhammadiyah as a social praxis movement, either through institution or statement or individual attitudes from the elites of leaders and young cadres and even recently it actively responds to the religious minority problems in Indonesia.

Besides becoming a mediator of conflict between Sunni-Shia in Sampang in line with the mandate given by the $47^{\text {th }}$ Congress in Makassar 2015, Muhammadiyah throughs the director of Lazismu. Hilman Latief voiced an urgency for the religious philanthropy institutions to be concerned with the religious minority groups in Indonesia. Alms and various other charity funds should be distributed by prioritizing the religious minority groups that have experienced expulsion, persecution, and who still stay in the refugee camps which are not decent during the recent years. Although it is not easy since it is always criticized by a number of Islamic groups, when it is compared with the distribution of the alms adopting the old or conventional pattern where the poor should have in a queue in front of the houses of the rich and this sometimes caused some victims, this step should be seriously considered. ${ }^{38}$

Meanwhile, in the aspect of education, Muhammadiyah has established a number of higher education in East Indonesia, where the majority of students are non-Muslim. Then, Research and Development of the Higher Education Council of the Central Board of Muhammadiyah are composing a Guide for Al-Islam and

\footnotetext{
37 Kuntowijoyo in Alwi Shihab, Membendung Arus: Penetrasi Gerakan Muhammadiyah terhadap Misi Kristen di Indonesia (Yogyakarta: Suara Muhammadiyah, 2016), xv.

38 According to Hilman, the old pattern in distributing alms may potentially cause some commotion and victims due to jostling, stepping on each other from long queues, as once happened to in Pasuruan in mid-September 2008. Read further in Hilman Latief, "Philanthropy and 'Muslim Citizenship' in Post-Suharto Indonesia", Southeast Asian Studies, Vol. 5, No. 2 (2016), 269-289.
} 
Kemuhammadiyahan (AIK) with a Multicultural Perspective. ${ }^{39}$ As an additional course, the AIK material for non-Muslim students is written with the goal as the scientific studies which are made objectively, openly and without any indoctrination. As a result, the package of the AIK lecturing with a Multicultural Perspective is translated into "Islam dan Agama-agama Dunia, Etika Islam, dan Study Kemuhammadiyahan" (Islam and World Religions, Islamic Ethics, and Study of Muhammadiyah) (as a derivation or reproduction from AIK I, II, and III). The orientation of the materials and the approach to the study are different from those of AIK I, II, and III for Muslim students in general. ${ }^{40}$ With the new formula, it is expected that this course is expected to position the non-Muslim students as outsiders who want to know, learn and deepen Islamic knowledge like learning Islamology.

The various efforts made are an answer to Muhammadiyah in responding to the more plural challenges of the times. There is no distinction of skin color, race, and faith since once more diversity is a challenge that should be faced together as a nation. Appreciation to diversity has been taught by the Holy Qur'an as stated in al-Māidah:

39 The concept of "AIK with the Perspective of Multiculturalism" is a change in nomenclature of "Non-Muslim AIK".This formula is composed together between Research and Development of the Higher Education Council of the Central Board of Muhammadiyah and the Drafting Team from the University of Muhammadiyah Malang consisting of Prof. Dr. Syamsul Arifin, M.Si., Dr. Moh. Nurhakim., Pradana Boy ZTF Ph.D., Nafik Muthohirin, MA.Hum. The formula of AIK with the Multiculturalism Perspective has been discussed in Focus Group Discussion twice, first, it was conducted in the Office of Central Board of Muhammadiyah Yogyakarta on Saturday (16/8/2019) by inviting a number of experts such as Prof. Dr. Abdul Munir Mulkhan, Prof, Dr. Syafaatun Almirzanah; Prof. Dr. Sutrisno, M.Ag; Prof. Dr. Syamsul Arifin, M.Si; Prof. Dr. Tobroni, M.Si; Nafik Muthohirin, MA.Hum; Dr. Ustadi Hamsah; Budi Asyhari Afwan; dan Ahmad Muttaqin, Ph.D, and some others.

40 AIK I (Islam and the World Religions) is oriented into its various dimensions (by collecting perspectives of religious studies and multiculturalism), meanwhile AIK II (Islamic ethics) gives a priority of Islamic values which are rahmat li al-'aälamin in nature: private (domestic), public (or social) and natural values while AIK II (Study of Kemuhammadiyahan) is meant to introduce Muhammadiya as an advanced and modern Islamic organization that may give a great contribution to the building of human civilization and dignity. The Study of Kemuhammadiyahan avoids any doctrinal aspect of the organization, but implant values of Islamic Ethics guiding them to build civilization and humanity. It is Cited from the "Draft of AIK with a Multicultural Perspective", as the material for FGD in Yogyakarta, (Saturday, $15 / 8 / 2019)$. It is not publicly published. 
8-10 (be fair), al-Maun (care to each other), al-Hujurāt: 12 (not hostile to each other), and al-Hujurāt: 10 (knitting togetherness). Therefore, Muhammadiyah is doing some objectification intended to defend and align to the religious minority groups, in this case, is especially conducted by the young Muhammadiyah intellectuals, implied to two responses from the citizens of Muhammadiyah, namely the group that accepts and that does not accept it. The group that accepts it thinks that objectification is an effort to renew thoughts in the body of Muhammadiyah. This group consists of among other young cadres of alliance and heads of Muhammadiyah some of whom have connections with the alumni of State Islamic University (UIN) working in centers for studies, NGOs, and as researchers. This group is open to any thoughts of modern countries such as human rights, democracy, gender, pluralism, Islamic economy, and the concept of the nation-state. The openness of the attitudes and thoughts of this group gives impacts on various inclusive and transformative programs of Muhammadiyah's movements. One of the examples is AIK with the Multicultural Perspective since one of its initiators is Budi Asyhari Afwan. Whereas the other group, namely the party that refuses the objectivation sturdily supports the doctrine of purification since this group thinks that objectivation is susceptible to any superficiality of faith. Some parts of this group are the leaders of Mumahhadiyah connected to the administrators in the Indonesian Ulema Council (MUI). Certainly, this argument cannot be generalized that all leaders becoming the administrators in the Council possess such perspective. However, to identify them, it can be traced from the refusal among them to the contemporary discourse such as pluralism, non-Muslim leadership, gender, the existence of religious minority groups such as Shia and Ahmadiyya that were included in the fatwa that they are misguided in 2005.

Moreover, this objectification also answers the modernity needs in the body of Muhammadiyah and confirms a vital role of the organization I responding to the nationality matter. Firstly, it asserts that the identity of Muhammadiyah is an organization standing on the renewal of religious thoughts. Up to now, there has been a tendency among a small part of scholars who call the modernization in the body of Muhammadiyah in the aspect of the charity venture management, and this does not happen in the aspect of thoughts. Even those who dod not understand the historical root of this 
movement say that Muhammadiyah experience conservatism since it adopts Wahabism that is developing in the Middle East blindly. At the best knowledge of the authors, the argument should be straightened. A blind assumption that juxtaposes between Wahabism and Muhamamdiyah purification is a form of misdirection of thinking, since, purification which is developing in Muhammadiyah is greatly different. The influence of the radical and conservative ideology of Wahabism and Ibnu Taimiyah tends to be ignored or not to be seriously responded to by the citizens of Muhammadiyah. Even since the beginning, Muhammadiyah possesses a characteristic of renewal by supporting ideas of reforming religious thoughts, organizational leadership, and management. Muhammadiyah adopts a model of organizational leadership that is developing in the West ${ }^{41}$ and refers to the renewal of the movement and thoughts of Jamāl al-Dīn alAfghānī, Muhammad 'Abduh dan Muḥammad Rashīd Riḍā.

Secondly, the attendance of the young Muhammadiyah intellectuals who are brave to voice their alignment to the religious minority groups is one of the real roles played by Muhammadiyah in supporting plurality and the commitment of unity in diversity, especially by basing it on the objectification of the religious doctrine, so it no wonder that this brave effort often justifies them as a liberal group in Muhammadiyah. ${ }^{42}$ Without objectification, this organization will lose the elan vital of this struggle as an advanced movement. The effort of the objectification is very crucial so that this organization will not experience old-fashioned thinking action and an exclusive behavior in its social interaction, especially in knitting togetherness with communities with different faiths, races, ethnic groups, and groups.

\section{Concluding Remarks}

Young Muhammadiyah intellectual own a significant role in showing the alignment to the religious minority groups in Indonesia.

\footnotetext{
41 Suaidi Asyari, "A Real Threat from Within: Muhammadiyah's Identity Metamorphosis and the Dilemma of Democracy", Journal of Indonesian Islam, Vol. 1, No. 1 (2007), 18-19.

42 Justification as this liberal group mentions a lot in researches. One of them may be seen in Suaidi Asyari, "A Real Threat from Within...., 19 may also be read in Martin van Bruinessen, "What Happened to the Smiling Face of Indonesian Islam? Muslim Intellectualism and the Conservative Turn in Post-Soeharto Indonesia", RSIS Working Paper. No. 222 (6 January 2011), 1-45.
} 
The shape of their alignment is actualized in two features of movements namely: 1) advocacy of social and economic empowerment and also policy empowerment; 2) scientific publications that include research reports, journal writings, books, opinions, and statements of attitudes in social media. Although their alignment tends to the second style of the movement, their responsiveness to any issues which are considered to be controversial is a brave action and should be appreciated. Even this movement emerges from the internal cycle of Muhammadiyah possessing experiences of refusal to various religious minority issues in previous years.

The attitudes adopted by the young Muhammadiyah intellectuals in paying attention to the minority issues start from the objectification of the verses in the Holy Qur'an containing alignment to the mustad'afin group that becomes the basis of Muhammadiyah as a renewal movement (tajdid). The progressive young people interpreted mustad'afin as the struggle of the religious minority problems. Because a number of religion-based conflicts once become a dark portrait for plurality in Indonesia during the last two decades. Communal violence which is based on religion will always potentially emerge when identity politics is stronger.

As a result, the religious minority problem is a new challenge that should be seriously attended for the Muhhammadiyah movement in the second century of its journey. In the more modern era, it is challenging to refuse new interpretations of this movement beside it is a necessity, it is also caused by a stronger tendency of the appearance of strong fanatism of certain religious groups that threatens the harmony of the religious life in Indonesia.

\section{Bibliography}

Abdurrahman, Moeslim. Suara Tuban, Suara Pemerdekaan. Yogyakarta: Kanisius, 2009.

Akmaliah, Wahyudi. "Tekanan Massa dan Vonis 2 Tahun Ahok", Geotimes, Tuesday, 9 May 2017.

Arsyad, Lincolin. "Workshop Panduan AIK untuk Non-Muslim" di UMM Inn Hotel Malang on 4 November 2017.

Asyari, Suaidi. "A Real Threat from Within: Muhammadiyah's Identity Metamorphosis and the Dilemma of Democracy", Journal of Indonesian Islam, Vol. 1, No. 1, 2007. 
Beck, Herman L. "The Rupture between the Muhammadiyah and the Ahmadiyyah", Bijdragen tot de Taal, Land- en Volkenkunde (BKI), 161-2/3, 2005.

Brown, Gustav. "Civic Islam: Muhammadiyah, NU and the Organisational Logic of Consensus-making in Indonesia", Asian Studies Review, Vol. 43, No. 3, 2019.

Bruinessen, Martin van. "What Happened to the Smiling Face of Indonesian Islam? Muslim Intellectualism and the Conservative Turn in Post-Soeharto Indonesia", RSIS Working Paper. No. 222, 6 January 2011

Burhani, Ahmad Najib. "The Ahmadiyya and the Study of Comparative Religion in Indonesia: Controversies and Influences", Islam and Christian-Muslim Relations, Vol. 25, 2013.

----- "Kang Moeslim dan Muhammadiyah", Kompas, 9 July 2017.

-----. "Kelompok Minoritas sebagai Kategori Mustad'afin", Suara Muhammadiyah, 15 February 2019.

-----. Menemani Minoritas: Paradigma Islam tentang Keberpihakan dan Pembelaan kepada yang Lemah. Jakarta: Gramedia, 2019.

Crouch, Melissa. Indonesia, Militant Islam, and Abmadiyya: Origins and Implication. Melbourne: ARC Federation Fellowship, Centre for Islamic Law and Society, Melbourne Law School, University of Melbourne, 2009.

Fanani, Ahmad Fuad. "Kebinekaan di Persimpangan Jalan". Koran SINDO, "Opini”, Thursday, 2 July 2015.

Hilman Latief, "Philanthropy and 'Muslim Citizenship' in PostSuharto Indonesia", Southeast Asian Studies, Vol. 5, No. 2, 2016.

Interview with Ahmad Muarif di Kantor PP Muhammadiyah Yogyakarta on 1 July 2019.

Interview with Budi Ashari Afwan on 16 August 2019.

Interview with Budi Ashari on 16 August 2019.

Interview with Yulianti Muthmainnah on 7 August 2019.

Kersten, Carool. Berebut Wacana: Pergulatan Wacana Umat Islam Indonesia Era Reformasi, trans. M. Irsyad Rafsadie. Bandung: Mizan, 2018.

Makin, Al. Nabi-nabi Nusantara: Kisah Lia Eden dan Lainnya. Yogyakarta: SUKA-Press, 2017.

Menchik, Jeremy. Islam and Democracy: Tolerance Without Liberalism. Cambridge: Cambridge University Press, 2016. 
Mu'ti, Abdul and Ul-Haq, Fajar Riza. Kristen-Mubammadiyah: Konvergensi Muslim dan Kristen dalam Pendidikan. Jakarta: Al-Wasath Publishing House, 2009.

Munawar-Rachman, Budhy. Reorientasi Pembaruan Islam: Sekulerisme, Liberalisme, dan Pluralisme Paradigma Baru Islam Indonesia. Jakarta: Pusat Studi Agama dan Multikulturalisme-The Asia Foundation, 2010.

Muthmainnah, Yulianti. "In the Name of Majority, Forgotten of Minority", presented in the Winter School on Pluralism and Development Program, by International Institute for Studies in Race, Reconciliation and Social Justice at the University of the Free State in Bloemfontein South Africa in cooperation with the University for Humanistic Studies in the Netherlands, Bloemfontein - South Africa from 16 July - 10 Aug 2012.

Muthohirin, Nafik. "AIK Non-Muslim: Menjawab Tantangan Pendidikan Islam", Suara Muhammadiyah 24/102. Edisi 16-31 December 2017.

-----. "Perkuat Kebersamaan: Muhammadiyah Gelar Silaturrahim Lintas Agama", Suara Mubammadiyah, 6 August 2016.

----. "Tokoh Agama belum Berperan Maksimal Wujudkan Toleransi", Suara Muhammadiyah, 10 August 2016.

Ropi, Ismatu. "Islamism, Government Regulation, and the Ahmadiyya Controversy in Indonesia", Al-Jamiah, Vol. 48, No. 2, 2010.

Shihab, Alwi. "The Muhammadiyah Movement and Its Controversy with Christian Mission. Dissertation--Temple University, 1995.

Shihab, Alwi. Membendung Arus: Penetrasi Gerakan Mubammadiyah terbadap Misi Kristen di Indonesia. Yogyakarta: Suara Muhammadiyah, 2016.

Syafii Maarif, Ahmad. Islam dalam Bingkai Keindonesiaan dan Kemanusiaan: Sebuah Refleksi Sejarah. Jakarta: Mizan, 2009.

ZTF, Pradana Boy. "Kang Moeslim, Selamat Jalan (Mengenang Moeslim Abdurrahman 6 July 2012)". Geotimes, rubrik "Kolom", Thursday, 6 July 2017. 